\title{
Mucin histochemistry of the columnar epithelium of the oesophagus: a retrospective study
}

\author{
JR JASS
}

From the Department of Histopathology, Westminster Medical School, Horseferry Road, London

SUMMARY Reflux oesophagitis may be accompanied by replacement of squamous epithelium by? columnar epithelium (Barrett's oesophagus). The columnar epithelium may resemble either gastric or $\stackrel{\omega}{+}$ intestinal mucosa, though ultrastructural and histochemical studies indicate that the intestinal type ${ }_{\infty}^{\infty}$ does not necessarily resemble normal small intestine. Twenty-two malignant and 10 benign oeso-尺 phageal specimens were examined histologically and by mucin histochemistry in an attempt to classifyo the various types of columnar epithelium. An incompletely differentiated variant of intestinal $\rightarrow$ metaplasia secreting sulphomucins was associated with well but not poorly differentiated adenocarcinomas ( $p<0.02$; Fisher's exact test). Similar findings have been described in the stomach and incomplete intestinal metaplasia may be related to disorders of growth and differentiation described $\stackrel{\text { S }}{+}$ in other sites such as the colon. These observations may help in the interpretation of oesophageal $\ddot{\infty}^{\circ}$ biopsies, possibly permitting identification of patients at risk of developing oesophageal adeno-.-. carcinoma.

It is generally accepted that adenocarcinoma of the oesophagus may arise from columnar epithelium of the distal oesophagus, acquired as a result of peptic reflux. ${ }^{1}$ It is also accepted that the columnar epithelium may either be gastric or intestinal in type, ${ }^{1}$ though histochemical and ultrastructural studies suggest that this classification may be an oversimplification. ${ }^{2-4}$ This paper poses the following questions: can mucin histochemistry help to characterise oesophageal columnar epithelium? Do well differentiated adenocarcinomas frequently arise in intestinal-type epithelium as in the stomach ?5-6 Is an incompletely differentiated variant of intestinal metaplasia secreting sulphomucins associated with well differentiated adenocarcinomas, as in the stomach?? Can mucin histochemistry help in the interpretation of oesophageal biopsies and the identification of a high-risk group of patients?

\section{Material and methods}

The material included 22 surgical resections for adenocarcinoma of the oesophagus, one resection for a benign peptic stricture showing columnar epithelium, and nine benign biopsies taken at oesophagoscopy purporting to include ectopic

Accepted for publication 4 February 1981 columnar epithelium. This material was collectedő from patients attending Westminster Hospital since 1948. Thirteen of the tumours arose near the gastro-윽 oesophageal junction, but were included in the study because the description and (if available) photograph indicated that the greater part of the lesion was contained within the oesophagus.

Serial sections were cut from each block andostained with haematoxylin and eosin, periodic. acid-Schiff (PAS)-diastase (d), alcian blue (AB) pH 2.5 with PAS- $\mathrm{d}^{8}$ and high iron diamine (HID) with AB. ${ }^{9}$ The latter two combinations permitted distinction between acid and neutral and between sulpho- and sialomucins respectively.

\section{Results}

For the purposes of this study, tumours were divided into those with and without well differentiated areas.0 The latter resembled intestinal epithelium, sinceo goblet cells secreting acid mucins and columnar cells్ with at least a partially developed brush border were? represented. The columnar cells frequently differedo from normal enterocytes however in showing mucin droplets in the apical cytoplasm (Fig. 1). Well differentiated areas, including in particular the columnar cells, secreted mainly sulphomucins Sialomucins and neutral mucins were the predominant 


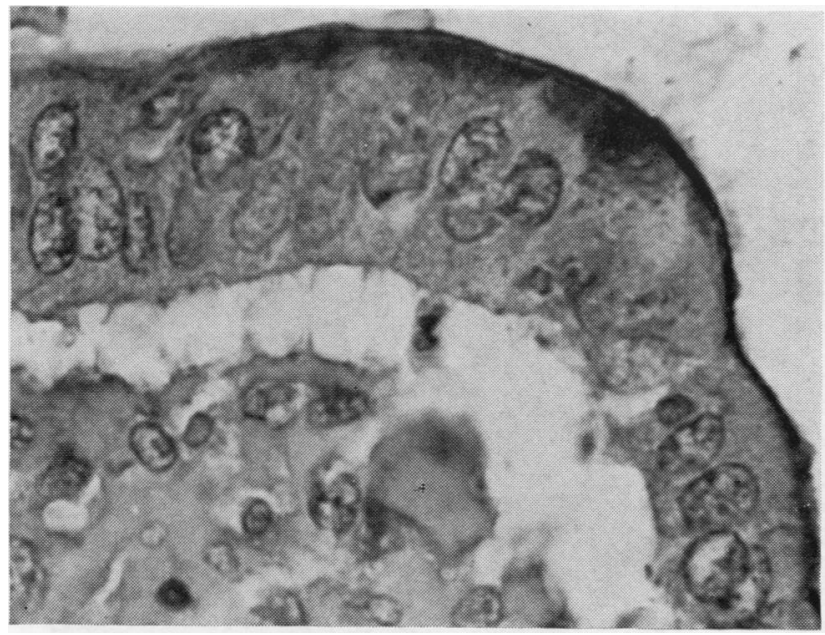

Fig. 1 Well-differentiated adenocarcinoma with columnar cells showing intermediate characteristics. At least a partially developed brush border is present yet the apical cytoplasm contains basophilic mucin droplets (identified as a sulphomucin on the serial sections). Haematoxylin and eosin $\times 100$ (original magnification)

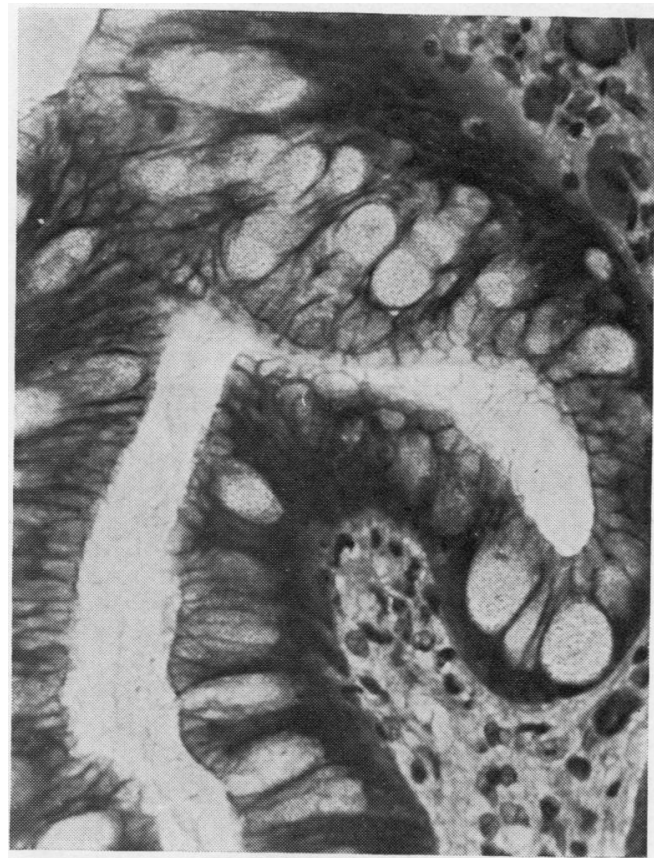

Fig. 2a

secretion in poorly-differentiated tumours.

Benign columnar epithelium resembled either gastric or intestinal mucosa. Both fundic and cardiac glands (and intermediate forms) were observed in gastric epithelium and mucins were mainly neutral in type. Intestinal epithelium was characterised by barrel-shaped goblet cells secreting acid mucins. The intervening columnar cells rarely resembled normal absorptive enterocytes however. Their brush border

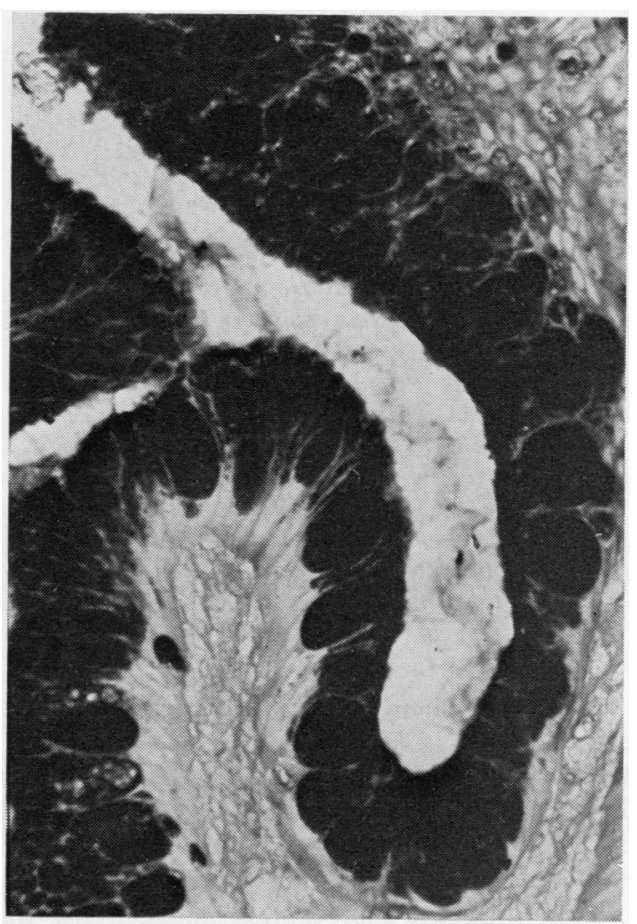

Fig. 2b

was variably developed and sometimes absent and the apical cytoplasm contained mucin droplets. When, on occasion, the columnar cells resembled normal enterocytes, the epithelium was termed complete intestinal metaplasia (IM) type I (though Paneth's cells were not observed). When the columnar cells secreted mucins the epithelium was designated incomplete IM type II. Type II IM was further subdivided into IIA when neutral mucins predomin- 


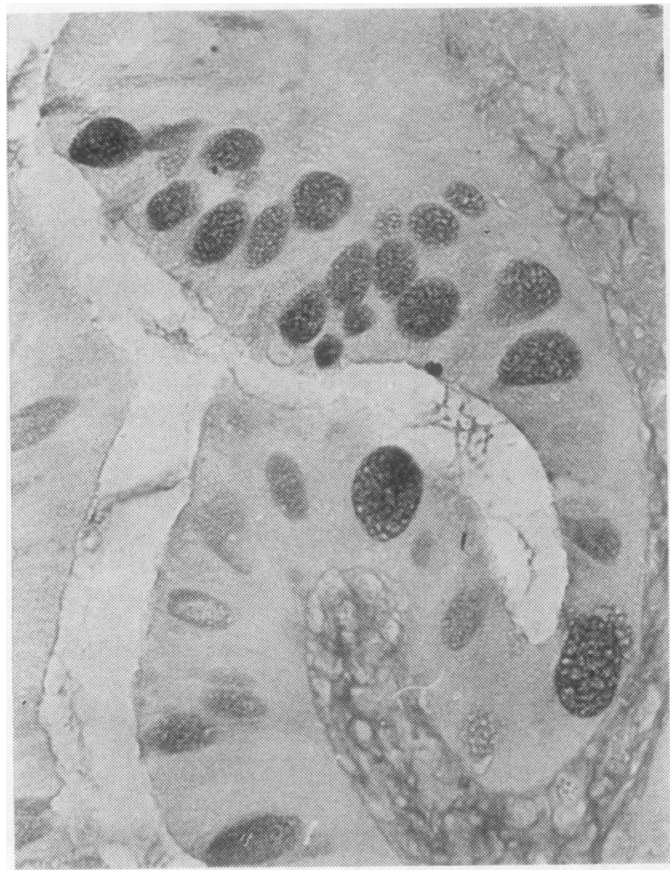

Fig. 2c

Fig. 2 An oesophageal biosy from a patient with dysphagia (but no carcinoma) showing incomplete intestinal metaplasia, type IIA. (a) haematoxylin and eosin (b) periodic acid-Schiff-diastase (c) high iron diamine-alcian blue. Two populations of mucous cells, but no absorptive cells are present. The barrel-shaped goblet cells and the intervening columnar cells are PASpositive. With HID-AB the majority of the goblet cells are $A B$ positive only, indicating sialomucin secretion (grey) whereas the intervening cells are negative since they secrete neutral mucins. $\times 63$ (original magnification)

ated and IIB when sulphomucins predominated (Figs. 2 and 3).

The incidence of all types of columnar epithelium bordering the well and poorly differentiated adenocarcinomas is given in the Table. Often two or more types of columnar epithelium occurred in the same case, explaining the discrepancy between the total number of observed types of epithelium (18) bordering the well differentiated tumours (15 cases). The distribution of columnar epithelium in the ten benign oesophageal specimens differed from the malignant cases, in that gastric and type IIA IM were the most common and extensive types of columnar epithelium. Five examples showed gastric epithelium, three type IIA IM and two mixtures of both. Type IIB IM occurred focally in three cases which also showed extensive type IIA change. Type

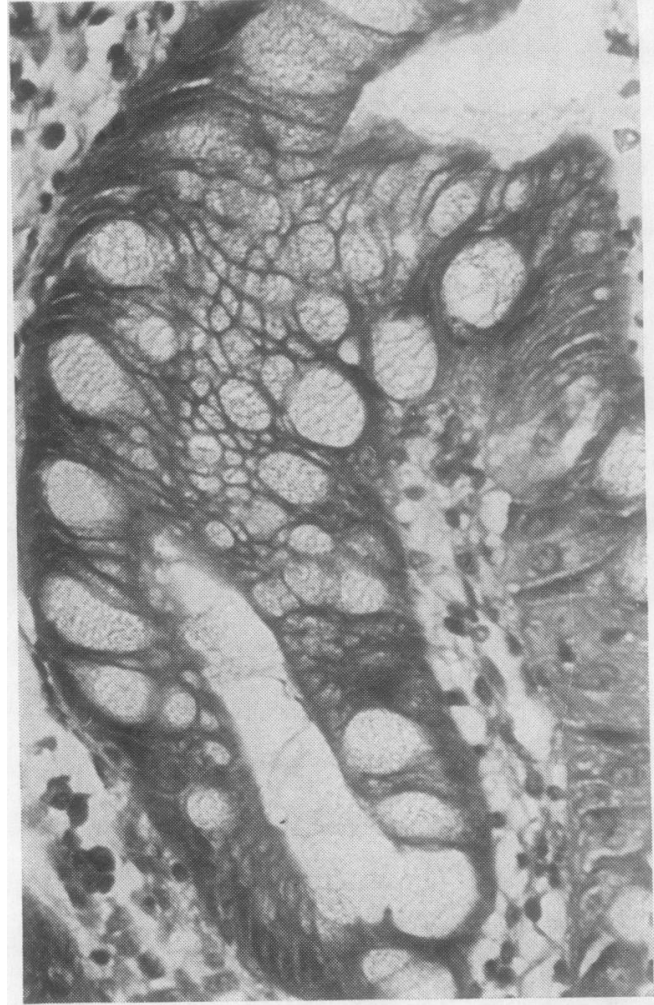

Fig. 3a

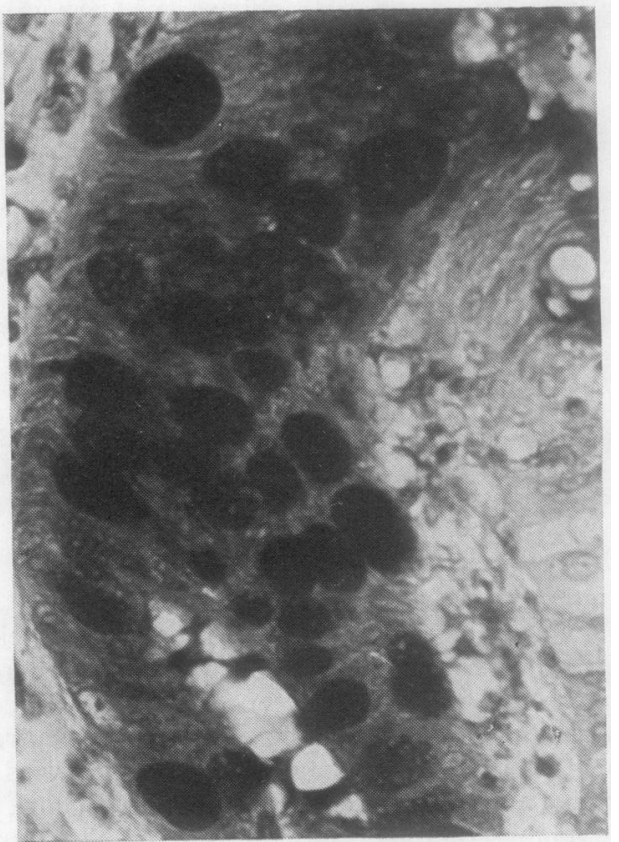

Fig. $3 b$ 


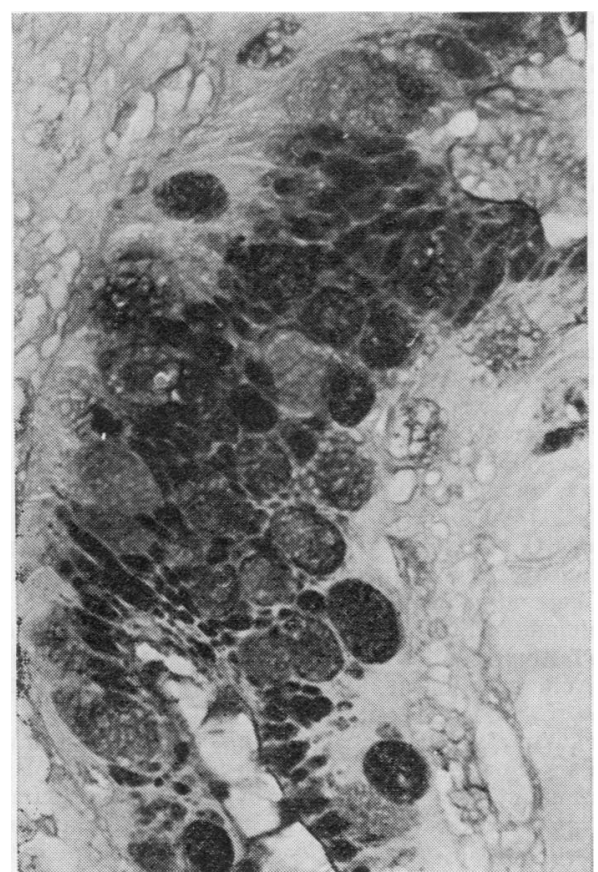

Fig. 3c

Fig. 3 Incomplete intestinal metaplasia, type IIB, taken from a specimen showing a well differentiated adenocarcinoma (not shown). (a) haematoxylin and eosin (b) periodic acid-Schiff-diastase (c) high iron diaminealcian blue. Like IIA IM, two populations of mucous cells can be discerned. The goblet cells are strongly positive with PAS-D. Unlike type IIA IM, the intervening columnar (intermediate) cells show slight (but definite) $P A S$ reactivity. However with $H I D-A B$, the columnar cells are HID positive (black) indicating sulphomucin secretion. They also reveal at least a partially developed brush border. The majority of the goblet cells are $A B$ positive with $H I D-A B$, indicating sialomucin secretion (grey). Note the frankly dysplastic cells to the right. $\times 63$ (original magnification)

Incidence of various types of columnar epithelium in well and poorly differentiated adenocarcinomas

\begin{tabular}{|c|c|c|}
\hline & $\begin{array}{l}\text { Well differentiated } \\
\text { adenocarcinomas (15) }\end{array}$ & $\begin{array}{l}\text { Poorly differentiated } \\
\text { adenocarcinomas (7) }\end{array}$ \\
\hline $\begin{array}{l}\text { Gastric epithelium } \\
\text { Intestinal metaplasia: }\end{array}$ & 4 & 1 \\
\hline $\begin{array}{l}\text { Type I } \\
\text { Type IIA }\end{array}$ & 2 & $\begin{array}{l}0 \\
0\end{array}$ \\
\hline Type IIB & 9* & 0 \\
\hline
\end{tabular}

*Significant association of type IIB intestinal metaplasia with well differentiated adenocarcinoma ( $p<0.02$; Fisher's exact test).

I IM was observed as a focal change in only one specimen. Type I IM was therefore rare in both benign specimens and bordering tumours.

\section{Discussion}

The columnar epithelium of the oesophagus has been classified into two main types, either resembling gastric (fundic or cardiac) or intestinal epithelium. ${ }^{1}$ Ultrastructural studies have shown that the intestinal type does not necessarily resemble normal small intestine. ${ }^{24}$ In place of normal absorptive enterocytes, there are columnar mucous cells bearing a partially developed microvillous border. Small intestinal enzymes may be demonstrated along the brush border, but in trace amounts. ${ }^{3}$ These cells appear to show features which are intermediate between a mucous and an absorptive cell and their counterparts have been observed in partial intestinal metaplasia (IM) in the stomach. ${ }^{10}$ They will be referred to as intermediate cells hereafter.

Mucin histochemistry showed the intermediate cells to differentiate along two principal lines, secreting either neutral or sulphomucins. Type IIB IM (with intermediate cells secreting sulphomucins) was associated with well but not poorly differentiated adenocarcinomas ( $p<0.02$; Fisher's exact test). It is also relevant that type IIB IM and well differentiated adenocarcinomas shared similar mucin profiles, with sulphomucins predominating. Furthermore, the columnar cells in well differentiated adenocarcinomas frequently resembled intermediate cells (Fig. 1). These factors suggest a histogenic link between type IIB IM and well differentiated adenocarcinomas. The negative correlation between type IIB IM and the poorly differentiated adenocarcinomas is evidence that the change is not merely secondary to tumour growth. The origin of the poorly differentiated adenocarcinomas is uncertain, since columnar epithelium (gastric type) was observed in only a single case. Congenital gastric heterotopias occur as small islands scattered throughout the oesophagus 4 and could conceivably give rise to and subsequently be destroyed by a tumour. The submucous oesophageal glands are another possible source. Five of the poorly differentiated adenocarcinomas arose near the gastro-oesophageal junction and whilst the greater part of the tumour was contained within the oesophagus, it is also possible that a proportion may have been of gastric origin. The tumours were highly selected in all being amenable to surgical resection and this may explain the preponderance of well differentiated adenocarcinomas in the study.

It is interesting to compare the findings with recent observations made on the stomach in which type IIB IM (secreting sulphomucins) was also associated with well-differentiated or "intestinal" adenocarcinomas. ${ }^{7}$ Similar findings have been reported by others. ${ }^{11-13}$ On the other hand, type IIA IM (secreting neutral mucins) was associated with benign gastric 
lesions. ${ }^{7}$ Likewise in this study, type IIA IM was a frequent and extensive change in benign oesophageal biopsies, whereas type IIB IM occurred only focally. However the number of cases was tno few to permit statistical analysis. Prospective studies are needed to show whether type IIB IM may serve as a useful premalignant marker.

The precise nature of the intermediate cell is not known for certain. It is tempting to compare it with its namesake in the generative zone of normal intestinal epithelium. ${ }^{14} 15$ The intermediate or oligomucous cell as described in detail in the colon, is an immature "undecided" cell showing both absorptive and secretory features. ${ }^{15}$ It is probably able to differentiate ultimately into either an absorptive or a mucous cell. ${ }^{14}$ Hyperplasia of intermediate cells occurs in a number of disorders of growth and differentiation in the colon including both adenomatous and metaplastic polyps ${ }^{15}$ and transitional epithelium bordering colonic carcinomas ${ }^{16}$ and a similar process could be operating in the incomplete intestinal metaplasias of the stomach and oesophagus. Clearly further detailed studies are needed to characterise this ubiquitous family of immature cells.

I thank Dr MI Filipe for her help and guidance, the laboratory staff for staining numerous sections, Mrs A Leaver for typing the manuscript and my clinical colleagues for allowing me to study the cases.

\section{References}

${ }^{1}$ Morson BC, Dawson IMP. Gastrointestinal pathology 2nd ed. Oxford: Blackwell Scientific Publications, 1979.

2 Trier JS. Morphology of the epithelium of the distal esophagus in patients with midesophageal peptic strictures. Gastroenterology 1970;58:444-61.

${ }^{3}$ Berensen MM, Herbst JJ, Freston JW. Enzyme and ultrastructural characteristics of esophageal columnar epithelium. American Journal of Digestive Diseases 1974;19:895-907.

4 Ozzello L, Savary M, Roethlisberger B. Columnar mucosa of the distal oesophagus in patients with gastroesophageal reflux. In: Sommers SC, Rosen PP, eds. Pathology annual Vol 12. New York: Appleton-CenturyCrofts, 1977:41-86.

${ }^{5}$ Laurén P. The two main types of gastric carcinoma; diffuse and so-called intestinal type carcinomas. An attempt at a histo-clinical classification. Acta Pathol Microbiol Scand 1965;64:31-49.

- Nakamura K, Sugano H, Takagi K. Carcinoma of the stomach in incipient phase: its histogenesis and histological appearances. Gann 1968;59:251-8.

7 Jass JR. Role of intestinal metaplasia in the histogenesis of gastric carcinoma. J Clin Pathol 1980;33:801-10.

${ }^{8}$ Mowry W. Alcian-blue techniques for the histochemical study of acidic carbohydrates. $J$ Histochem Cytochem $1956 ; 4: 401$.

' Spicer SS. Diamine methods for differentiating mucosubstances histochemically. J Histochem Cytochem 1965; 13:211-34.

${ }^{10}$ Ming SC, Goldman H, Freiman DG. Intestinal metaplasia and histogenesis of carcinoma of the human stomach. Cancer 1967;20:1418-29.

${ }^{11}$ Heilmann KL, Höpker WW. Loss of differentiation in intestinal metaplasia in cancerous stomachs. A comparative morphologic study. Pathol Res Pract 1979;164:249 58.

18 Matsukura N, Suzuki K, Kawachi T, et al. Distribution of marker enzymes and mucin in intestinal metaplasia in human stomachs and relation of complete and incomplete types of intestinal metaplasia to minute gastric carcinomas. Journal of the National Cancer Institute 1980;65: 231-40.

${ }^{13}$ Sipponen P, Seppälä K, Varis K, Hjelt L, Ihamaki T, Kekki M, Siurala M. Intestinal metaplasia with colonictype sulphomucins in the gastric mucosa; its association with gastric carcinoma. Acta Pathol Microbiol Scand 1981 ;(in press).

${ }^{14}$ Merzel J, Leblond CP. Origin and renewal of goblet cells in the epithelium of the mouse small intestine. Am J Anat 1969;124:281-306.

${ }^{15}$ Kaye GI, Fenoglio CM, Pascal PR, Lane N. Comparative electron microscopic features of normal, hyperplastic and adenomatous human colonic epithelium. Gastroenterology 1973;64:926-45.

16 Dawson PA, Filipe MI. An ultrastructural and histochemical study of mucin changes in the colonic mucosa adjacent to and remote from carcinoma. Cancer 1976 37:2388-98.

Requests for reprints to: Dr JR Jass, Department of Histopathology, Central Middlesex Hospital, Acton Lane, London NW10 7NS, England. 